\title{
EL SIDA EN EL ESCENARIO GAY: MELODRAMA DIDÁCTICO VS LOCURA CÁUSTICA. ESTUDIO COMPARATIVO: A TU INTOCABLE PERSONA DE GONZALO VALDÉS MEDELLÍN Y UNA VISITA INOPORTUNA DE COPI
}

\author{
Pauline Rousseau \\ École Normale Supérieure de Lyon
}

\section{RESUMEN}

A partir de los años ochenta apareció un tema nuevo en el escenario social y cultural gay: el sida. Tanto las dramáticas consecuencias que la enfermedad tuvo en la comunidad como los discursos discriminadores que provocó fueron temáticas clave de numerosas obras de teatro. Las dos obras que aquí se comparan se centran en esta temática. No obstante, a pesar de ciertas semejanzas, como el cuadro ficcional o los personajes, cada autor configura un sistema de representación que, si bien comprende la lucha contra la discriminación, utiliza técnicas teatrales muy distintas. La risa trágica de Copi y el didacticismo dramático de Valdés Medellín parecen proponer dos formas de resistencia que se inscriben en un contexto histórico y cultural particular, pero que reflejan también metas artísticas y políticas singulares que este artículo se propone estudiar.

\section{PALABRAS CLAVE}

Teatro gay, Sida, Representación, Resistencia artística

\section{ABSTRACT}

In the 80 's, a new topic emerges on the social and cultural gay stage: AIDS. The terrible consequences of AIDS on the community, together with the discriminant talks awaken around the illness become the main theme of many plays. The two plays compared here focus on this subject. However, excluding some similarities such analogous places or characters, both authors stage very different representative systems and theatrical technics, while both fight against discrimination. Copi's tragic laugh and Valdés Medellín's dramatic didacticism seem to purpose two distinct kinds of resistance, each one coming 
from a common cultural and social context but reflecting distinctive goals, both on the artistic and political side. This article aims to study what these differences mean and reveal.

KEY WORDS

Gay Theater, AIDS, Representation, Artistic resistance 
"Los artistas son los actores principales de una historia que jamás les pertenece" Dieudonné Niangouna, Acteurs de l'écriture

\section{INTRODUCCION}

A tu intocable persona (Valdés Medellín, 1994)

y Una visita inoportuna (Copi, 1988) son dos obras teatrales centradas en la misma temática: la aparición del Virus de Inmunodeficiencia Humana (VIH) y las consecuencias de la enfermedad del Síndrome de Inmunodeficiencia Adquirida (sida) en "el ambiente" y en la sociedad. Ambas obras presentan similitudes notables. La situación ficcional es idéntica: un personaje homosexual enfermo de sida(Orlando en A tu intocable persona, Cyrille en Una visita inoportuna) se encuentra en el hospital y recibe visitas diversas. Las más de las veces, las obras teatrales presentan un conflicto que los personajes intentan resolver. Aquí, la enfermedad es un pretexto para articular en el argumento conversaciones y perspectivas acerca de la temática del sida, la homosexualidad y la muerte. Los personajes secundarios son similares. Son los familiares (la madre de Orlando y su novio Leonardo en la obra de Valdés Medellín; Hubert, el gran amigo de Cyrille, en la obra de Copi), o representantes del mundo médico (doctores y enfermeras). En ambas obras aparece también un reportero, idea que subraya la dimensión pública y polémica de la temática en la época. Además de las semejanzas en el cuadro ficcional, las dos obras se pueden considerar como teatro gay. Son ficciones que hacen numerosas referencias al mundo del "ambiente", presentan a personajes homosexuales

1 "Les artistes sont les personnages principaux d'une histoire qui n’est jamais la leur.” [Mi traducción.] y adoptan un punto de vista crítico hacia las normas heterosexuales y patriarcales. Las puestas en escena participan del proceso de visibilización de la homosexualidad, a través del dispositivo teatral, para resistirse a la hegemonía homofóbica y a los regímenes discursivos de condena. Este fenómeno es lo que Antonio Marquet (2001: 332) llama la problemática del "darse cuenta". Sin embargo, esas analogías permiten resaltar profundas diferencias en la manera de acercarse a un tema contemporáneo y se propone un teatro gay que luche contra los estereotipos. Tales diferencias nos permiten analizar cómo cada autor configura un sistema de representación que, si bien comprende la lucha contra la discriminación, utiliza técnicas teatrales muy distintas. La risa trágica de Copi y el didacticismo dramático de Valdés Medellín parecen proponer dos formas de resistencia que se inscriben en un contexto histórico y cultural particular, pero que reflejan también metas artísticas y políticas singulares. Antes de analizar esas obras, conviene situar el panorama cultural y político de cada una y algunos elementos biográficos de los autores.

A tu intocable persona es una obra mexicana publicada en 1994 pero cuya historia se sitúa en $1985 .{ }^{2}$ Se presenta como una ficción aunque varios personajes parecen directamente inspirados en la realidad. Una visita inoportuna es una obra francesa publicada en 1988 cuya acción es contemporánea de la escritura. Esta pieza se construye a partir de un hecho real: la 2 Esta fecha es simbólica dado que en 1985 los poderes públicos reconocen oficialmente la existencia de la enfermedad, tres años después del descubrimiento del primer caso de infección en México. 
estancia de Guy Hocquenghem ${ }^{3}$ en el hospital y la experiencia del propio autor. Copi falleció el 14 de diciembre de 1987 durante los ensayos de la obra, la cual se estrenó pocas semanas después. Al momento de escribir Una visita inoportuna, Copi se sabía enfermo de sida, lo que no le impidió declarar a la prensa: "por supuesto que tengo sida, si sigo todas las modas" (Copi, 1988: 93). Esta cita es emblemática del humor mordaz del caricaturista argentino; una risa franca y cínica que atraviesa su repertorio teatral. Exiliado de la dictadura argentina, Copi llegó a Francia en 1963, a los 24 años. Rápidamente se hizo famoso con las caricaturas de la "femme assise" ("la señora sentada") publicadas cada semana en Le Nouvel Observateur. Copi fue una figura emblemática del mundo artístico gay del París de los años 1970 $\mathrm{y}$, aunque no se haya considerado nunca como militante, frecuentó un grupo donde el límite entre la militancia, la vida y el trabajo era lábil. Fue muy amigo de Guy Hocquenghem (co-fundador del FHAR), ${ }^{4}$ colaboró en el diario Libération, con otras figuras importantes del movimiento como Hélène Hazera, Serge Daney y Michel Cressole. A partir de 1966, Copi publicó obras teatrales que trastornaron los códigos dominantes. El escenario de Copi está poblado por marginados (travestis, transexuales, árabes, homosexuales, drogadictos, madres infanticidas, etcétera). En sus obras, Copi ataca todos los tabúes: el amor y la muerte, el

3 Figura famosa del mundo artístico parisino, Guy Hocquenghem transformó su habitación de hospital en lugar mundano donde recibía a todas las figuras emblemáticas del mundo cultural parisino para tomar una copa de champán. El propio Copi acudía frecuentemente a esas reuniones.

4 Front homosexuel d'action révolutionnaire (Frente Homosexual de Acción Revolucionaria). dinero, el crimen, el sexo, la sexualidad y, sobre todo, la identidad. No se preocupa por lo que puede pensar el público, habla de lo que no se quiere hablar, ríe de lo que se considera serio y muestra lo que no se quiere ver.

Gonzalo Valdés Medellín pertenece a una generación posterior. Nace en 1963 (año en el que Copi llega a Francia) y tiene 19 años cuando aparece el primer caso de sida en México. Valdés Medellín es autor de teatro, director escénico y crítico; cuando en 1994 publica $A$ tu intocable persona ya es reconocido. ${ }^{5} \mathrm{La}$ obra tuvo un gran éxito: se dieron 300 representaciones y recibió ocho Arlequines en 1995. El autor siempre se declaró homosexual: "Yo soy homosexual, siempre lo he sido y a nadie le he ocultado mi identidad sexual. Me molesta mucho que se utilice como una bandera, una bandera... no sé para qué. Lo importante es el ser humano" (Medellín, 2005). El autor considera su teatro como "homoerótico" más que "gay", y afirma buscar "una obra que habla del ser humano, que llega a mover las fibras sensibles de cualquier persona" (Medellín, 2005). Al estreno de $A$ tu intocable persona, Valdés Medellín recibió varias críticas por parte de la comunidad:

José María Covarrubias llegó al teatro El Galeón a decir: ¿por qué nos pones así? Pues por que así

5 Gonzalo Valdés Medellín fue becario del FONCA en dramaturgia en 1989, y en dirección en 1994. Entre sus obras destacan Las criadas (de Jean Genet), La última noche con Laura (de Federico S. Inclán), Corazones apasionados en mares del buzón sentimental y La carcajada de Genet). Es colaborador de Siempre! Y lo fue del suplemento Sábado. Recibió el Premio Casa de América Latina del XII Concurso de Cuento Juan Rulfo en 1995 por En la casa de las semejanzas y el Premio José Pagés de Crónica en 1999. 
somos. Y él: pero la gente no tiene que saber que nos ligamos en los baños y que mamamos en la calle. Perdóname, eso lo hizo Luis Zapata en los setenta y nadie le fue a decir no publiques tu libro. Y sin embargo, llegaba gente enferma de sida, grupos de misioneros católicos, paulinos, agustinos, de varias cofradías católicas a llenar el teatro, a llenarlo porque algo les decía (Medellín, 2005).

La referencia al Vampiro de la colonia Roma, de Zapata, novela que relata las aventuras de un chichifo (un prostituto homosexual) en el México de los años 1970, es interesante. De hecho, esta novela narra de manera muy directa los encuentros sexuales del héroe en espacios de "convivencia homosexual". Lo que parece decir José María Covarrubias es que en 1994, diez años después de la aparición del VIH, ya no se puede hablar de la homosexualidad como antes, especialmente en lo que concierne al sexo libre y plural. La respuesta de Gonzalo Valdés Medellín aboga por la necesidad de abrir el tema a toda la sociedad, incluso a "los misioneros y a las cofradías católicas" porque como lo menciona el reportero en la obra: “¿Cómo al lector no le va a parecer doloroso un caso así? [...] Esto es una historia de amor. Una historia de amor echada a perder por... no es posible. Parece tan sencillo" (Medellín, 1994: 6). La idea de una obra que "llega a mover las fibras sensibles del espectador" se expresa claramente aquí. Frente a los discursos homofóbicos que Gonzalo Valdés Medellín experimentó probablemente siendo un joven homosexual en los años ochenta, aboga por lo "humano" y el aspecto "conmovedor" de una historia de amor echada a perder por culpa de ciertos estereotipos como la asociación entre sida y homosexualidad. Sensibilizar, más que chocar, parece ser la línea de Gonzalo Valdés Medellín. Esta diferencia con Copi se puede explicar en parte por el contexto político y cultural de cada obra, panorama que conviene revisar.

Afinales delos años sesenta y particularmente durante los años setenta, aparecieron en distintos países como Estados Unidos, Francia y un poco más tarde México, colectivos de defensa de las "minorías sexuales". Para el movimiento lésbicogay, ${ }^{6}$ la primera reivindicación fue la de una existencia pública y libre, es decir, una salida del "clóset social", de las normas impuestas por distintas instancias como la familia, la escuela, la Iglesia y el Estado. Los colectivos políticos y militantes organizaron acciones públicas como marchas, talleres y grupos de reflexión. Paralelamente a estos grupos oficiales, nació de

6 En Francia, los primeros colectivos fueron el FHAR, de ideología neomarxista, creado en 1971 por Guy Hocquenghem, entre otras personas, y por las "gouines rouges", movimiento de lesbianismo radical. Las "gouines rouges", fundado en 1971 por disidentes del MLF (Movimiento de Liberación de la Mujer, cofundado en 1970 por Monique Wittig y Antoinette Fouque, entre otras), colaboró con el FHAR para hacer un frente homosexual unido. A pesar de la indignación de la mayor parte de las organizaciones sindicales y políticas de izquierda, participaron, junto con los travestis, en la marcha del 1 de mayo de 1971, gritando consignas como: "Nacionalicemos las fábricas de lentejuelas." Sin embargo, a partir de 1975, la "gouines rouges" regresaron al MLF ya que consideraron el FHAR como un movimiento machista. En México, la primera marcha gay ocurrió en 1979. Reunió tres colectivos: el FHAR, movimiento internacional y exclusivamente masculino, de ideología similar al movimiento francés; Oikabeth (Olling Iskan Katuntat Bebth Toth: movimiento de mujeres guerreras que abren camino y esparcen flores), grupo exclusivamente femenino y de ideología feminista radical que prolongaba Lesbos, fundado por Yan María Castro; y por último, Lambda, cocreado por Xabier Lizárraga Cruchaga después de la disolución de Sex-Pol, que era el único grupo mixto en la época y estaba muy influenciado por el feminismo. 
manera más informal lo que se puede llamar una comunidad. Desde finales de los años setenta y hasta finales de los ochenta, se dio una fase de apertura de lugares dedicados a la "sexualidad alternativa". No fueron necesariamente lugares de militancia pero sí espacios donde los encuentros se hacían en función de la sexualidad. Según Barry D. Adams (1998: 221) se puede hablar de "organización gay de la homosexualidad":

Un mundo gay surgió en el momento en que la homosexualidad se convirtió en el principio organizador de un comportamiento social según el cual los hombres que tenían tendencias homosexuales se encontraban los unos con los otros por el hecho de ser homosexuales y no sólo por la existencia de relaciones sociales previas. Hombres con tendencias homosexuales creaban así lugares semi clandestinos en el ámbito público, lugares que inevitablemente caían bajo la vigilancia de los patrocinadores morales y de la policía. ${ }^{7}$

Estos lugares se convirtieron poco a poco en espacios de "sociabilidad gay", configurados como un mundo aparte, que progresivamente fue reivindicadoporlosaficionados. Comolomenciona Adams, la configuración de una "comunidad" implicaba la formación de redes sociales, y del establecimiento de lugares comunes donde la sexualidad se podía vivir libremente. Poco a poco,

7 "A distinctive gay world originated at the moment when homosexuality became an organizing principle of social behaviour under which homosexually interested men came in contact with each other because of their homosexuality and not simply as an outgrowth of existing social relation. Men with homosexual interests carved out semi clandestine places in the public realm - places that inevitably fell under the surveillance of the moral entrepreneurs and police." [Mi traducción.] se trataba de ir más allá de las preferencias sexuales para configurar una identidad propia y colectiva, lejos de los estereotipos del discurso excluyente. Varias dinámicas artísticas acompañaron este proceso de "salida del clóset social". Numerosas obras de teatro y películas participaron en el proceso de recuperación-reconfiguración de la “identidad gay". El teatro en particular sirvió para promover un sistema de auto-representación, retomando por ejemplo los códigos del "ambiente" y proponiendo una representación del homosexual fuera de los estereotipos de la sociedad excluyente ${ }^{8}$ o denunciando el sistema de violencias físicas, verbales y simbólicas que sufrían los homosexuales. En Francia, el movimiento empezó realmente con la creación del FHAR en 1971.

Al principio de los años ochenta apareció un elemento perturbador en el mundo gay: en 1981, fue diagnosticado el primer caso de VIH en Estados Unidos. En esos años, "la plaga rosa" o el "cáncer gay" fueron términos empleados para calificar esta enfermedad. Tales metáforas demuestran la identificación que se hacía entre la homosexualidad y la enfermedad y, por asociación de ideas, entre mala conducta y castigo. Este virus hasta entonces desconocido, y cuyos efectos eran particularmente desgastantes, ${ }^{9}$ levantó polémica.

8 Numerosos militantes como Nancy Cárdenas, Xabier Lizárraga Cruchaga y Juan Jacobo Hernández, en México, y Guy Hocquenghem, Jorge Lavelli o Copi, en Francia, son autores o directores de teatro. Por lo tanto, es lógico que este arte en particular se haya usado como medio para llevar el discurso de la comunidad al escenario.

9 Según las cifras de Onusida (Organismo Mundial afiliado a la ONU para la lucha contra la epidemia), el sida había contaminado a 78 millones de personas en 2014, mientras que 39 millones de personas han muerto a causa de esta 
Los discursos homofóbicos solían situar la enfermedad entre el castigo divino y la peste moderna. El modo de propagación, esencialmente mediante el uso de jeringas usadas o por relaciones sexuales no protegidas, confirió al sida un aspecto de sífilis moderna: "con el sida, es la primera vez que los enfermos son considerados a la vez como víctimas y responsables" (Lizárraga Cruchaga, 2011). Así, el sida se convirtió en una de las armas más eficientes de la política del miedo, extendida en toda la sociedad y dirigida contra el otro: el otro abyecto, el otro decadente, el otro peligroso para el cuerpo social y, por lo tanto, castigado por una inexplicable enfermedad. En un primer momento, los políticos intentaron esconder la aparición del virus, retomando una política bien conocida por las minorías sexuales: el ocultamiento. Luego, al no poder evitar lo que se hacía ya evidente — dado el altísimo número de muertos- estigmatizaron a las víctimas, convirtiendo la enfermedad en un arma contra la "decadencia moral".

Frente a estos discursos, los grupos que defendían a las minorías sexuales intentaron organizarse y luchar de manera conjunta contra el virus y la homofobia. Ante el abandono de las políticas de salud pública, los distintos colectivos llevaron a cabo acciones para informar y sensibilizar a la población. De igual modo, las artes también abordaron esta temática, que se volvió central en el teatro gay a finales de los años ochenta. Las más de las veces, esa década se ve como un momento de "hibernación" de la

enfermedad desde su descubrimiento. En la actualidad, el sida es la enfermedad viral con más alto número de muertos. Información disponible en internet: www.unaids.org/fr (consultado el 12 de enero de 2015.) movilización a favor de las minorías sexuales, hibernación directamente ligada a la necesidad de luchar contra la enfermedad (Díez, 2010: 144145). Esta cuestión merece más precisiones. De hecho, si bien los colectivos dejaron de lado la dinámica de visibilización comenzada con las marchas y los talleres pocos años antes, la lucha interna en pro de la prevención y la difusión de información acerca de una enfermedad de la cual no se hablaba, no puede ser caracterizada como una "ausencia de actividad". La cuestión de la "representación", de la imagen que uno se hace de un homosexual enfermo de sida, es un elemento clave de esta lucha. Al representar personajes homosexuales, drogadictos, enfermos de sida, travestis, el teatro aparece como un espacio privilegiado para mostrar una realidad oculta, para tomar la voz y jugar con los estereotipos. A la vez ficcional y real, funciona como "heterotopía" según la definición de Foucault. Es un espacio que permite proyectarse en la ficción y volver a sí mismo con una mirada que quizá haya cambiado (Foucault, 1984: 46-49). El teatro no hace la revolución pero puede participar en el cambio de mentalidades mediante la representación de lo que se oculta.

Si bien las dos obras de nuestro corpus se centran en la temática del sida, presentan entre sí notables diferencias en la forma y en la manera de trastocar los códigos dominantes. Valdés Medellín propone un tratamiento didáctico, cercano a una concepción clásica del teatro político tal como lo puede definir Piscator (1930: 27): "un medio político para llegar a diversos fines." En este sentido, el teatro político tiene como meta actuar 
sobre el público, es decir, llevarlo a pensar la posibilidad de un cambio en la sociedad. El teatro de Valdés Medellín se puede considerar como teatro político en este sentido. Elabora su análisis a partir de elementos reales y cotidianos y propone una reflexión al espectador sobre los aspectos nefastos de la discriminación, particularmente hacia los enfermos de sida. Por su parte, Copi no parece desarrollar ningún discurso político explícito. Su obra se presenta más bien como una farsa delirante sostenida por una tensión trágica. El final inevitable se anuncia desde el principio, pero al mezclar una construcción trágica con los códigos de la farsa propone una obra en la cual los códigos formales y las referencias a la norma dominante son sistemáticamente invertidos. Esos elementos producen un efecto paradójico sobre el espectador ya que sus expectativas se desvían sistemáticamente. En Copi, uno se ríe del enfermo de sida; en Valdés Medellín, uno llora por su destino.

La comparación de estas obras nos permite ver cómo cada una de ellas se inscribe de manera distinta en un proceso de visibilización, o según las palabras de Marquet (2001: 332), en la problemática del "darse cuenta". Analizaremos cómo la elección de una estética teatral induce un tratamiento particular de la sexualidad, de la enfermedad y de las relaciones interpersonales relacionadas con un contexto cultural y social particular y una meta política y artística singular. Estudiaremos en primer lugar la dimensión del "teatro gay" y cómo ambas piezas, cada una a su manera, proponen una forma de auto representación de la comunidad apenas creada.
Después, veremos cómo los personajes que encarnan el discurso médico, supuestamente objetivo y garante de cierta "seriedad", aparecen en cada obra. Este elemento nos permitirá poner en relieve ciertas diferencias esenciales. Finalmente, analizaremos cómo cada obra se enfoca sobre un tema particular: el sida en el caso de Valdés Medellín y la muerte en el caso de Copi, y cómo tal elección implica una forma teatral particular y significativa para el propósito de cada autor.

\section{EL MUNDO GAY EN EL ESCENARIO: AUTORRETRATO DE LA COMUNIDAD}

Los códigos de la vida nocturna homosexual Ambas obras, A tu intocable persona y Una visita inoportuna, presentan ciertas semejanzas en la representación de algunas costumbres de la comunidad. La vida nocturna - llena de amantes puntuales, de gozos robados a la moral y de escondites - se presentó como un elemento clave del “ser gay" (Laguarda, 2009) en la época, cualquiera que fuese el país. De hecho, los movimientos gay se apoyaron en una de las primeras reivindicaciones del movimiento feminista: lo personal es político. El movimiento no implicaba sólo la reivindicación de practicar una sexualidad libre, plural y fuera de ciertas normas, sino el derecho de hablar de sexualidad públicamente. Los lemas de mayo del 68 en Francia demostraron la voluntad de asociar a la revolución política comunista de lucha de clase, la revolución sexual sin la cual la liberación del individuo no podría ser completa: "Más hago el amor, más hago la Revolución, y más hago la Revolución, más hago el amor", "Gozo en el 
pavimento"10 (Martel, 2008 [1996]: 31). Al poner en tela de juicio los modelos dominantes como la pareja heterosexual y la familia nuclear, los revolucionarios del sexo afirmaban conseguir una revolución absoluta. Las nociones de gozo y de placer sin limitación moral fueron centrales en las reivindicaciones y se consideraron como demandas políticas. En este contexto de fuerte represión, las artes constituían vías privilegiadas para representar el mundo con el cual soñaban los revolucionarios, ya que en la ficción todo es posible. Obviamente la llegada del sida frenó la dinámica libertadora. En la comunidad, la contaminación fue masiva y rápida. Además, la enfermedad sirvió como pretexto para quien quería condenar esta liberación. En las dos obras que se analizan, los personajes se refieren a esta vida nocturna intensa y en ambos casos la defienden como el "único modo de vida" posible.

En el primer acto de $A$ tu intocable persona, Orlando habla con la médica. Afirma no saber con cuántas personas se ha acostado ya que "le gusta mucho hacer el amor":

Orlando: ¡Vieja...! ¿Cómo voy a saber con cuántos me he acostado si me gusta mucho hacer el amor? [...] Pero la verdad no siempre se hace el amor [...] Sí, o sea, se tienen relaciones sexuales, pero sin nada de amor. A veces un rapidito en el baño de un Vips o un Sanborns, en la calle o donde sea. Lo único que se necesita es un chavo que te guste o tú le gustes a él o los dos se quieran o los dos estén calientes, y ya. [...] Me salgo en la calle, me pierdo en la ciudad (Valdés Medellín, 1994: 28).

10 "Plus je fais l'amour, plus je fais la Révolution; plus je fais la Révolution, plus je fais l'amour", "Je jouis dans les pavés”. [Mi traducción.]
Orlando relata una costumbre bien conocida en el mundo gay: "salir a los bares, perderse en la ciudad", y encontrar una pareja casual y momentánea. Orlando precisa que no necesariamente se "hace el amor". Veremos a continuación que la cuestión del "amor" es otra gran temática de las obras de teatro gay. Los homosexuales se encuentran principalmente en espacios públicos. El aficionado conoce los códigos y los lugares clave que le permitirán satisfacer su deseo. Orlando menciona dos referencias bien conocidas en México: los Vips y los Sanborns. Copi, por su parte menciona "les jardins des Tuileries" y "les pissotières" (los baños públicos) como espacios clave de la "homosexualidad" nocturna. Sin embargo, esas costumbres son consecuencia directa de la represión moral y social en la época. La necesidad de esconderse (del vecindario, por ejemplo) obligaba a los homosexuales a encontrarse en lugares públicos, es decir, anónimos. Esos lugares, obviamente bajo vigilancia, eran bastante peligrosos y se podían tener "malos encuentros", con la policía por ejemplo (Lizárraga Cruchaga, 1985: 12). Es interesante observar cómo Orlando retoma esta forma de relación, impuesta por las normas sociales. En su réplica, esta vida sexual intensa, anónima y fuera de las normas se presenta como una fuente de gozo. Una forma de actuar que no parece estar dispuesto a abandonar.

La obra de Copi presenta referencias similares. Cuando Hubert — el amigo de Cyrilleentra en su habitación, Cyrille le pregunta: "Y ¿qué hace por la noche ya que no estoy aquí para distraerle?" Inmediatamente, le pregunta por su vida nocturna. 
Hubert: Nada maestro. París ya no es la capital de antes. Desde que cerraron el Boeuf sur le toit, no se sabe qué hacer después de los espectáculos. Por otra parte, tampoco hay espectáculos. Y los que quedan, ya no son punto de reunión de galanes del tercer sexo ni de la tercera edad. Uno puede siempre pasearse por los Tuileries, pero tengo miedo que me roben la cartera $^{11}$ (Copi, 1988: 23).

Hubert se refiere al teatro como "punto de reunión" y menciona los jardines de las Tuileries como área clave de la sociabilidad homosexual. Podemos notar de paso que estas referencias marcan cierto medio social y cultural más bien alto y, sobre todo, parisino. Hubert se decepciona de esos lugares. Dice que ya no son tan amenos para los homosexuales que califica de "tercer sexo". Esta denominación -que se refiere tanto a la expresión común para calificar a los homosexuales como al artículo de Hirschfieldpermite a Hubert un paralelismo con "la tercer edad". Se califica a sí mismo de "anciano" y apunta una forma de exclusión del "mercado de la sexualidad", otro elemento que se encuentra en varias obras de teatro gay.

Ambas obras se refieren a lugares reales, tanto en México como en París. Estos sitios son emblemáticos de lo que Adams llama "los espacios de sociabilidad gay", lugares que participan en la configuración de una identidad colectiva. Estos "efectos de realidad" (Barthes,

11 'Hubert. Rien, maitre. Paris n'est plus la capitale d'autrefois. Depuis la fermeture du Bæuf sur le toit, on ne sait plus que faire après le spectacle. D'ailleurs, il n'y a plus de spectacles. Et s'il en reste, ce n'est plus un endroit de rencontre pour la gent galante du troisième sexe ni du troisième âge. On peut toujours se promener aux Tuileries, mais j'ai peur de me faire voler mon portefeuille.” [Mi traducción.]
1968), tienen una doble función. Son referencias explícitas para el público gay, una suerte de guiños dirigidos a los aficionados, y participan de la ruptura con los tabúes: afirman que se puede (y se debe) hablar de todo, especialmente de sexo. Este elemento resulta central en el teatro gay, en el cual los autores y directores - a menudo gay, pero no necesariamente - tienden a romper con los estereotipos discriminatorios (tanto el del gay "casado" como el del "gay triste y arrepentido"). ${ }^{12}$ Las dos obras defienden el gozo gay. La liberación de la lengua, del cuerpo y del sexo parecen ir a la par y ser indisociables de un actuar/ser gay. Sin embargo, la cuestión del amor podría ser un punto de inflexión entre ambas obras. Si bien esta temática es central y está encarnada por la pareja de Leonardo y Orlando en la obra de Valdés Medellín, el amor — con A mayúscula— está ausente de la obra de Copi, quien antepone a la pareja, el amigo de siempre.

\section{Amor y amistad en tiempos de sida}

Hasta 1996, no existe ningún tratamiento eficaz para curar el sida. Los enfermos son condenados a muerte de manera más o menos rápida. La confrontación con los que los rodean (familiares, amigos, pareja) es por lo tanto central en la problemática de la enfermedad. Antonio Marquet (2001: 333) señala la omnipresencia de parejas o de amigos en las obras que tratan del sida: "La constante en todas las

12 El movimiento Arcadie, uno de los primeros movimientos homosexuales en Francia, y fundado por André Baudry en 1951, exige a los homosexuales una conducta "decente" y reservada, a cambio de una tolerancia por parte de los heterosexuales. Es también contra esta representación del homosexual como pecador que se elevan movimientos como el FHAR. 
obras, es la referencia a la pareja: como búsqueda, como disolución, como intento de reconstitución... El amigo es el que finalmente tiene que apoyar para hacer frente al sida."

De hecho, ésa es una de las cuestiones principales que atraviesa la obra de Valdés Medellín. La pareja de Leonardo y Orlando, sus concepciones del amor, de la fidelidad, del vivir la sexualidad son temas recurrentes en los diálogos. Si para Leonardo la fidelidad es algo importante y simbólico, Orlando reivindica una sexualidad con diversos amantes, elemento que considera como una garantía de libertad. Afirma amar a Leonardo pero, como se lo explica, el hecho de ser homosexual implica para él tener prácticas sexuales libres, es decir múltiples.

Orlando: A veces te siento muy posesivo. Cuando me hablas de la fidelidad...

Leonardo: ¿Puedes imaginar lo que sentí cuando dijiste "hay que ser fieles pero no del todo"?, ¿por qué?, te pregunté...

Orlando (adelantándose): Porque somos hombres [...] Somos hombres, Leo. Nos gustan los hombres, no tenemos porque coartar nuestra libertad, de todos modos seguimos amándonos, ser fieles no es nada (Valdés Medellín, 1994: 40).

Para Orlando no sólo la fidelidad "coarta" la libertad, sino que no se relaciona a la noción de amor. Este discurso, muy frecuente en el mundo gay de los setenta y ochenta, hace eco de la reivindicación de una sexualidad libre y sin tabúes. Por otra parte, la fidelidad se ve a menudo asociada a un valor característico del amor burgués, contra la cual se configuró en un principio el movimiento de liberación sexual. Así lo menciona uno de los informantes de Laguarda en el capítulo "sexo y amor" de su libro: "Todos añorábamos tener una pareja. Nos sentíamos muy solos. Y cuando teníamos una ya nos hartábamos de la chingada pareja porque queríamos regresar al bar y salir con otros tipos" (Laguarda, 2009: 34).

En relación con el sida, esta cuestión es evidentemente central y no es casual que Valdés Medellín la ponga en primer plano. Como él mismo lo anunció, lo que le interesan son las relaciones humanas, en este caso, el Amor. Desde el principio, Leonardo afirma amar a Orlando "como loco". El sida representa la dolorosa perspectiva de perder a su amante. Podemos ver aquí un fondo melodramático que insiste en la dimensión sentimental y dramática de la relación. El final de la obra es relevante con respecto a la problemática planteada al principio. Cuando los médicos anuncian a Orlando que fue víctima de un error de diagnóstico, éste se precipita a la casa de Leonardo. Sin embargo, Leonardo, que desde el principio esperó una cura milagrosa de su amante, lo rechaza: "Leonardo: Tú has sido el amor de mi vida, lo sabes. Pero no podemos seguir juntos. [...] Todo lo que ha pasado ha sido espantoso, compréndelo, sería volver a lo mismo. Me duele decírtelo, pero te guardo rencor. El amor que te tengo, que te tuve, se ha ido llenando de amargura" (Medellín, 1994: 57). La muerte no separó a la pareja, pero la desgraciada aventura de la enfermedad sí. Los discursos discriminadores, las discusiones de pareja y las relaciones con el mundo exterior rompieron la historia de amor. Con insistencia en la dimensión sentimental, Medellín 
recurre a estrategias propias del melodrama para conmover al espectador y llevarlo a reflexionar sobre el daño que pueden hacer las palabras y los estereotipos.

En la obra de Copi, la cuestión de la pareja no aparece. De hecho, los sentimientos no resultan centrales y es la seducción la que se impone sobre el amor. Por ejemplo, Cyrille intenta seducir al joven que se presenta como "reportero", quien, al final resulta ser el sobrino de Hubert. Y aunque está en las puertas de la muerte, Cyrille no deja de lado una potencial aventura sexual. La obra de Copi no acude al registro melodramático, no busca conmover al público. Al contrario, la dimensión de farsa camp impone la risa sobre las lágrimas. Conviene aclarar la noción de camp que se utiliza aquí. Camp es una palabra que aparece en el lenguaje coloquial inglés a principios del siglo XX. En 1909, el Oxford English Dictionary lo define como: "ostentoso, exagerado, afectado, teatral: afeminado u homosexual". ${ }^{13}$ Camp se reserva a los varones y se emplea para calificar lo que se considera como un "actuar homosexual", es decir, la adopción por un hombre de un "estilo" - gestos determinados, una manera de hablar, de moverse, etcétera - considerado como femenino. El camp es por lo tanto un calificativo despectivo. Sin embargo, los homosexuales también recuperaron el camp — exagerando este lenguaje verbal y corporalpara burlarse de los heterosexuales. En este sentido, se reapropiaron el estigma - al igual que el queer más tarde. Tras la publicación de Notes on camp de Susan Sontag en 1964, la palabra se resignifica. Sontag define el camp como: "una estética"

13 "Ostentatious, exaggerated, affected, theatrical; effeminate or homosexual” [Mi traducción.] (aesthetic) y una "sensibilidad" (sensibility): "La esencia del camp es el amor a lo no natural: al artificio y la exageración"144 (Sontag, 1984 [1964]: 303). Para Sontag, el camp no puede considerarse como político: "Ni que decir tiene que la sensibilidad camp es no comprometida y despolitizada - al menos apolítica" (Sontag, 1984 [1964]: 305). Como lo definirá más tarde Jean-Yves le Talec (2008: 118): "El camp es una relación social que articula personas, situaciones, objetos y la homosexualidad. Se caracteriza por la incongruencia, la teatralidad y el humor". ${ }^{15}$ Después de los años setenta y las premisas del movimiento de "liberación sexual", el camp parece haber entrado en la arena política junto con el sexo y la sexualidad. Varios colectivos como las Gazolines (subgrupo del FHAR) o Las hermanas de la perpetua indulgencia reivindicaron una estética camp asociada a la figura de la "loca". Según Patrick Mauriès (1979: 9): "La palabra camp demostraba un ahondamiento (una reflexión) y una ampliación (espectáculo) de la noción de 'Loca'."16 A partir de esos años, el camp forma parte de las estrategias de resistencias culturales, se trata de derrocar los esquemas tradicionales de dominación y las categorías binarias (hombre/ mujer, naturaleza/ cultura, dominante/dominado), creando un "espacio de libertad para todos y todas"17 (Mauriès, 1979: 9). Como ya se mencionó, Copi se inscribe en esta

14 "Indeed the essence of Camp is its love of the unnatural: of artifice and exaggeration." [Mi traducción.]

15 "Le camp est une relation sociale qui met en jeu des personnes, des situations, des objets et l'homosexualité. Il se caractérise par l'incongruité, la théâtralité et l'humour". [Mi traducción.]

16 "Ce mot de Camp démontrait un approfondissement (réflexion) et élargissement (spectacle) de la notion de folle." [Mi traducción.]

17 "Un espace de liberté pour toutes et tous." [Mi traducción.] 
corriente política del camp que no promueve un discurso político o militante explícito pero se sitúa en lo que podríamos llamar un modo infrapolítico, utilizando el disfraz, el humor mordaz y la teatralidad para demostrar la ineficacia de las categorizaciones forzadas y de opresión.

La dimensión camp no impide que las relaciones interpersonales estén marcadas por cierta ternura matizada de humor cínico. Hubert se presenta como el amigo de siempre, llega primero a festejar el aniversario del contagio de sida de Cyrille, y la amistad es el tema de la primera conversación que tienen. Hubert se entristece por no tener más amigos:

Hubert: Es la verdad. Le tengo envidia. ¡Tengo terror de llegar a ser un centenario! ¡Si ya no sé qué hacer con mis días!

Cyrille: ¡Váyase a vivir al tercer mundo! Con su fortuna, puede reinar sobre una corte de efebos que le espanten las moscas con hojas de bananero.

Hubert: Ya lo pensé. Pero me da miedo sentirme demasiado lejos de mis amigos.

Cyrille: Sus amigos están todos muertos ${ }^{18}$ (Copi, 1988: 15).

Esta réplica es obviamente una referencia a la hecatombe del sida en el mundo gay. También se puede notar que "los amigos" a los que se refieren Cyrille y Hubert son los amigos gays. Esta dimensión comunitaria remite a la definición de Adams precedentemente citada: "Un mundo gay surgió en el momento en que la homosexualidad se convirtió

18 "Hubert. - C'est la vérité, je suis jaloux de vous. J'ai peur de vivre centenaire, car je ne sais déjà plus que faire de mes journées. / Cyrille. - Allez vivre dans le tiers monde ! Riche comme vous êtes, vous devriez régner sur une cour d'éphèbes qui vous éventent les mouches à l'aide de feuilles de bananier. / Hubert. - J'y ai songé. Mais j'ai peur de me sentir trop loin de mes amis. / Cyrille. - Ils sont tous morts, vos amis" (Copi, 1988: 15). [Mi traducción.] en el principio organizador de un comportamiento social". En la obra de Copi, la amistad excede la "normalidad" o el realismo. Hubert es el amigo que visita, pero es también el amante desesperado y excesivo que anuncia a Cyrille que le compró un mausoleo en el Père Lachaise: "justo frente a Oscar Wilde y al lado de Montherlant" (Copi, 1988: 15). Esta idea excéntrica enoja a Cyrille, quien le contesta: "iNo quiero que me entierren en ninguna parte! Me negué a usted desde el instituto, no crea que me va a arrinconar cuando esté muerto. ¡Viejo necrófilo!" (Copi, 1988: 15). Esta réplica cierra la tercera escena. Como lo subraya Michel Cournot en un artículo publicado en Le Monde y retomado en la edición del texto: "Copi convierte esta comediafarsa de la muerte en una fiesta de la amistad y en primer lugar, de la amistad entre homosexuales"19 (Cournot, 1988, en Copi, 1988: 94).

La amistad es probablemente el hilo conductor de la obra de Copi; el amor y la pareja, destrozada por los discursos discriminatorios, es el hilo de la de Valdés Medellín. Los autores toman partido distinto, pero siguen vinculados con ciertas temáticas emblemáticas de las obras de teatro gay. Valdés Medellín insiste en la dimensión amorosa, temática clave del melodrama. La meta es obviamente conmover al espectador y sensibilizarlo a la idea de que una historia de amor no tiene sexo. La obra de Copi presenta a dos viejos amigos homosexuales, "locas sublimes" que se siguen riendo de la soledad, la muerte y la enfermedad. Valdés Medellín enfoca su obra en discursos realistas, emblemáticos de 19 "Copi fait basculer cette comédie-farse de la mort vers une fête de l'amitié, et en premier lieu de l'amitié qui attache les homosexuels" (Copi, 1988: 94). 
la época e inmediatamente reconocibles. Copi, por su parte, evoca temáticas similares pero que aparecen subyacentes, sólo visibles por debajo de la capa de humor negro. Podemos concluir, por lo tanto, que Valdés Medellín intenta convencer al público, cuando Copi se propone distraerlo con una historia aparentemente no divertida.

Centrando su argumento en el sida, los autores no pueden evitar abordar ciertas temáticas y elementos, como el mundo médico y los discursos que convierten a la enfermedad en una cuestión social más que de salud. Esta representación da lugar a diversas interpretaciones según el cuadro que plantean los autores. Conviene analizar la representación del mundo hospitalario donde se cristalizan importantes diferencias.

OBRA A PUERTA CERRADA

EN UN ESPACIO (IN)HOSPITALARIO

Las dos obras se sitúan en un hospital, lugar que implica la presencia de dos personajes clave: el médico y la enfermera. Cabe mencionar que en la época, el hospital se presenta como la antesala de la muerte para los enfermos de sida, además de ser un espacio de exclusión y rechazo por parte del personal médico. Frecuentemente, los enfermos son estigmatizados, poco o mal curados, e incluso considerados como responsables de este nuevo "mal social". La encarnación del personal médico en ambas obras es simbólicamente interesante ya que, como lo establece Michel Foucault en $L a$ voluntad de saber (1976), los médicos aparecen a finales del siglo XIX como una de las piezas fundamentales del "dispositivo de la sexualidad", cuya meta consiste principalmente en la "normalización" de las prácticas sexuales juzgadas como disidentes. Al ser el sida considerado como una enfermedad de "marginales", los autores proyectan la imagen que tienen del mundo médico.

\section{Denuncia y crítica del discurso médico-moral}

En la obra de Valdés Medellín, los médicos (en particular la enfermera Rodríguez) condenan la sexualidad de Orlando. La obra pone en escena de manera muy explícita las ideas preconcebidas relativas al virus. Por ejemplo, la enfermera Rodríguez reconoce que los médicos diagnosticaron el sida a Orlando cuando el cura les confesó que Orlando era homosexual. Al final de la obra, este diagnóstico se revela incorrecto, pero la pareja no sobrevive a la situación. Este giro final permite al autor poner de relieve el carácter destructor de los prejuicios que asocian al sida con la homosexualidad, es decir "vicio" y "castigo". Por otra parte, el hecho que los médicos se hayan enterado de la enfermedad de Orlando a causa del cura muestra de manera implícita los vínculos entre dos órganos dedicados al "control de la sexualidad": la Iglesia y la medicina.

En esta obra, la enfermera Rodríguez encarna esta confusión entre una supuesta objetividad científica y la influencia de preceptos religiosos y morales. Muy católica, la enfermera condena firmemente la homosexualidad de Orlando y considera que el sida es un "castigo divino" a causa de su "desviación del buen camino". Este personaje vincula una violencia verbal y otra simbólica (Bourdieu y Passeron, 1970), dos violencias que resurgieron de manera brutal durante los "años del sida". La escena en la cual se revela esta posición es en sí misma violenta. Este recurso dramático permite 
al autor hacer sentir al público la brutalidad de tal discurso. Se trata de la última escena del primer acto, escena en la cual la enfermera anuncia a la madre de Orlando que su hijo tiene sida. Dos elementos del diálogo demuestran a la vez la condena moral por parte de la enfermera y los preceptos religiosos que rigen su postura. Por una parte, vincula de manera muy directa la enfermedad de Orlando con sus prácticas sexuales, o sea un comportamiento "desviante". Por otra parte, no vacila en afirmar que la madre es parcialmente culpable de la muerte inminente de su hijo, ya que no supo educarlo y llevarlo hacia el "buen camino".

Rodríguez: Son pruebas que Dios nos manda comadrita. Y está mal que se lo diga ahora, pero tal vez Orlando no sea el culpable.

Madre: ¿Culpable de qué?

Rodríguez: De su enfermedad, de su desviación. Muchas veces no sabemos educar a nuestros hijos, muchas veces ni siquiera tenemos conciencia de que ellos están viviendo igual que nosotros una vida muy difícil, pero por nosotros, por nuestra causa (Valdés Medellín, 1994: 27).

El discurso de la enfermera no puede ser más explícito. Considera al sida como una "prueba de Dios" y el paralelismo entre "enfermedad y desviación", subrayado por la anáfora "de su", establece una relación de causa-consecuencia entre los dos términos. Además, la madre es considerada como "culpable" de la muerte de su hijo ya que no supo evitar que éste fuera homosexual. La doble condena, hacia el hijo y hacia su madre, remite a dos elementos muy comunes de la época. Primero, la enfermera considera la enfermedad como "castigo divino", pieza clave de la política de estigmatización de los enfermos, promovida por las instituciones religiosas pero también políticas que no vacilaron en instrumentalizar el virus:

[...] las recientes afirmaciones de dos importantes sacerdotes brasileños, el obispo Falcáo de Brasilia, quien sostiene que el SIDA es "la consecuencia de la decadencia moral", y el cardenal de Río de Janeiro, Eugenio Sales, quien se queda entre dos aguas y describe el SIDA a la vez como "castigo de Dios" y como "venganza de la naturaleza". Más interesantes, porque sus fines son más complejos, son los patrocinadores seculares de este tipo de invectiva. Las ideologías políticas autoritarias tienen intereses creados en promover el miedo, la sensación de una inminente invasión por extranjeros, y para ello las enfermedades auténticas son material útil (Sontag, 1989 [1988]: 75).

Segundo, echa la culpa sobre la madre ya que considera que no supo educar a su hijo. En El amor demás, Elisabeth Badinter demuestra cómo la mujer adquiere mediante el papel social de "madre" un reconocimiento hasta entonces inexistente. No obstante, esta "consideración" lleva consigo una serie de obligaciones, especialmente la de educar a los hijos, y por lo tanto la responsabilidad pública de una "buena educación":

Se abrió paso la conciencia de que la madre no tiene exclusivamente una función "animal”, sino el deber de formar a un buen cristiano, a un buen ciudadano, un hombre, en fin, que encuentre el mejor lugar posible en el seno de la sociedad. La novedad reside en que se la considera como la persona más adecuada para asumir esas tareas. "La naturaleza", dicen, es la que le asigna esos deberes. Auxiliar del médico en el siglo XVIII, colaboradora del sacerdote y del profesor en 
el siglo XIX, la madre del siglo XX asumirá una última responsabilidad: el inconsciente y los deseos de su hijo [...] Al tiempo que el carácter grandioso y noble de esas tareas era objeto de exaltación, eran condenadas todas aquellas que no sabían o no podían desempeñarlas a la perfección. De la responsabilidad a la culpa no hubo más que un paso, que no tardó en franquear la aparición de la menor dificultad infantil. A partir de entonces se inició la costumbre de pedir cuentas a la madre... (Badinter, 1981 [1980]: 197-198).

Elisabeth Badinter propone una historia de esta responsabilidad. A partir del siglo XX, la madre es particularmente responsable de la “inconsciencia”y de los “deseos" de sus hijos, o sea, de los elementos analizados por Foucault relativos a la salud mental y a la sexualidad. El trayecto de la madre de Orlando parece ilustrar perfectamente la frase de Badinter: “de la responsabilidad a la culpa no hubo más que un paso". Si al principio la madre negaba tener algo que ver con la enfermedad de su hijo, al final afirma:

Madre: ¡Qué castigo, Dios mío! Mi Orlando se muere pagando un pecado que en realidad es mío. ¿Por qué no se mueren otros? ¿Por qué no se mueren...? ¿Por qué no le tocó al Leonardo ese? Pero yo he sido la única culpable, yo, yo [...] Qué asco, qué asco me da todo y qué vergüenza. No tengo cara con qué salir a la calle, yo soy la culpable, yo lo dejé (Valdés Medellín, 1994: 27).

Esta réplica demuestra la eficacia del discurso de la enfermera, que consiguió no sólo que la madre considerara la homosexualidad como un "pecado", sino que se viera como la "única culpable" de la muerte de su hijo. Hoy en día el discurso de la enfermera parece algo exagerado.
Sin embargo, considerando la violencia de las afirmaciones de los sacerdotes citados por Susan Sontag, este tipo de posiciones parece bastante realista en el contexto ficcional de la obra, o sea, el año 1985. El realismo forma parte de la meta política de la obra de Valdés Medellín. Trata de mostrar en el escenario la violencia de un discurso que se puede oír fuera del teatro.

Otro elemento que permite analizar la meta política del discurso es el efecto que el autor quiere suscitar en el espectador. El contexto ficcional tiende a provocar una forma de empatía hacia la madre que acaba de enterarse de la muerte inminente de su hijo. El contexto favorece cierto pathos que nos remiteala dimensión melodramática de la obra. La exageración de los sentimientos y la sucesión de desgracias son aspectos clave de este género teatral que busca conmover al espectador. Aquí, la madre es claramente un personaje melodramático. Sin embargo, lo interesante es que en el melodrama "tradicional", el personaje principal - generalmente una niña inocente- se encuentra bajo la dominación de un personaje nefasto y manipulador. Aquí no aparecen estos personajes emblemáticos. Extrapolando el género, se puede considerar que Orlando (y Leonardo) aparecen como víctimas inocentes de una coalición "hetero-moral" más o menos anónima y difundida en la sociedad que se empeña en condenar su historia de amor. De hecho, podemos notar que Valdés Medellín no propone un discurso abiertamente contestatario al de la enfermera (podemos observar, por ejemplo, que el periodista está ausente en la escena); por lo tanto, el papel de distancia crítica y analítica 
recae sobre el espectador, invitado a reflexionar a partir de la emoción de la escena. El público se sitúa en la posición privilegiada de un observador de los efectos desastrosos de la violencia verbal y simbólica expresada aquí. Sin capacidad de respuesta dentro del teatro, se puede esperar que los espectadores reaccionen a los discursos existentes fuera del escenario.

\section{Desviar las expectativas:}

payasos con batas blancas

Si la obra de Medellín recurre al realismo y al distanciamiento crítico para provocar una toma de conciencia por parte del público, Copi desconecta la ficción de toda referencia a la realidad, especialmente en lo que concierne a normas sociales y códigos de género. Desde el principio, la enfermera Bongo aparece como un personaje que invierte los estereotipos de género. Uno de los primeros diálogos gira en torno a una bata que la suegra de Cyrille acaba de regalarle. Cyrille la ve horrible y por lo tanto, la enfermera le pide que se la regale:

Cyrille: ¡No me diga que usted se pone este tipo de cosas!

Enfermera: Me gustaría quedarme en casa, pasearme todo el día en bata, pero no tengo tiempo. Es para regalársela a mi marido que está todo el día preparándome platitos (Copi,1988: 12). ${ }^{20}$

Desde el principio, la enfermera plantea una inversión de los códigos tradicionales de género. 20 "Cyrille : - Ne me dites pas que vous portez des choses pareilles. / Infirmière : - Je voudrais bien rester chez moi, à me balader en robe de chambre, mais je n'ai jamais le temps. Ce serait pour faire un cadeau à mon mari qui reste toute la journée à la maison à me mijoter des petits plats" (Copi, 1988: 12). [Mi traducción.]
Es ella quien trabaja mientras su marido se queda en casa cocinando. En la relación con el paciente, aparecen elementos no realistas. Lejos de condenar a Cyrille, la enfermera y el médico (designado como "profesor" ${ }^{21}$ en la obra) lo aprecian. Por ejemplo, lo llaman "maestro", referencia un tanto irónica a su pasado de actor. La cuestión de la homosexualidad tampoco es tema de debate y mucho menos de condena. De hecho, en otra conversación con la enfermera lo abordan directamente:

Cyrille: Habla como un homosexual.

Enfermera: Me pregunto si no hubiera sido mejor nacer homosexual. Usted se manejó muy bien en la vida. Cyrille: La adoro ${ }^{22}$ (Copi, 1988: 11).

Dada la situación de Cyrille, la noción de "manejarse bien en la vida" es relativa; no sólo la enfermera hace referencia a su pasado de actor famoso, sino que elude completamente la cuestión de la enfermedad. Estos elementos forman parte de la técnica de inversión propia de Copi. Alejándose del realismo, propone un mundo donde se desvían los códigos de la normalidad, opone al realismo un espejo deformador.

Las nociones de "buena moral" o de "decencia" están ausentes en la obra. Así, los personajes de la enfermera y del profesor juegan a invertir constantemente las reacciones que se 21 La designación de "profesor" significa que la persona obtuvo el certificado de medicina-la agrégation, en Francia-, otorgando a su personaje el grado universitario más alto. Copi intensifica el efecto de sorpresa y de ridículo: el público espera una eminencia de la ciencia y se encuentra con un payaso. 22 "Cyrille : - Vous parlez comme un homosexuel. / Infirmière : - Je me demande si je n'aurais pas mieux fait de naître homosexuelle. Vous vous êtes bien débrouillé dans la vie / Cyrille : - Je vous adore." (Copi, 1988: 11). [Mi traducción.] 
pueden esperar de su función. El profesor afirma tener como hobby la "lobotomía", acto que sólo practica "el domingo", y la enfermera y el profesor mantienen una relación siendo ambos casados. En lo referente a Cyrille, los dos lo animan a consumir drogas:

Enfermera: Le voy a agregar una pizca de Valium al goteo.

Cyrille: ¡No quiero tranquilizantes químicos! Prefiero fumar mi opio.

Enfermera: ¡Podría darme a probar alguna vez! Cyrille: ¡De ninguna manera! Quedaría incapacitada para agarrar una jeringa.

Enfermera: ¡Deme un poquito! Probaré este fin de semana con mi marido. [...] ¿Es bueno para hacer el amor? ${ }^{23}$ (Copi, 1988: 10).

Se esperaría que la enfermera condenara a Cyrille por fumar opio en el hospital $y$, al contrario, le pide que le regale un poco para probar. De nuevo, reacciona de manera contraria a lo que se podría esperar. Más tarde, la enfermera llega completamente drogada y afirma ver todo "en verde"; es Cyrille, el paciente, quien la regaña por haber consumido opio en el ejercicio de su función. El decorado hospitalario planteado por Copi es por lo tanto un espacio extraordinario, completamente desconectado del realismo.

La cuestión religiosa aparece sólo una vez en la obra y de manera irónica. En la escena 13, 23 "Infirmière: - J'ajouterai une pincée de Valium à votre perfusion. / Cyrille : - Pas de tranquilisants chimiques! Je préfère fumer mon opium! / Infirmière : - Il faudrait qu'un jour vous m'en fassiez goûter / Cyrille : - Pas question! Vous n'arriveriez pas à tenir une seringue! / Infirmière : Donnez-moi un petit morceau, j'essaierai avec mon mari. [...] C'est bon pour faire l'amour?" (Copi, 1988: 10) [Mi traducción.] el profesor se sorprende de lo que considera como un exceso de salud por parte de su paciente:

Profesor: Debemos investigar las causas de este exceso de salud. Si no, habrá que creer en un milagro.

Cyrille: ¡Espero que no me obliguen a convertirme! ¡Y menos aún hundirme en la piscina de Lourdes! Profesor: No tema. Sería solamente un milagro científico $^{24}$ (Copi, 1988: 28).

La referencia a la religión aparece de manera humorística y la perspectiva de una conversión se presenta en Cyrille como una pesadilla. En la obra de Valdés Medellín, Orlando promete convertirse al catolicismo si se cura, idea que abandona una vez que le anuncian que no tiene sida. La única referencia que se puede identificar aquí es una ironía respecto a la ciencia que se sueña como nueva religión, en búsqueda de "una verdad absoluta". Toda la obra se constituye de reacciones inesperadas por parte de la enfermera y del profesor que contestan sistemáticamente a la inversa de lo esperado.

Pese a que las figuras médicas de ambas obras son totalmente distintas, tienen como único elemento en común la incapacidad de los médicos para curar a los pacientes. La obra de Valdés Medellín se centra en la voluntad de mostrar a los médicos, y en particular a la enfermera, como emblemas de la discriminación de una sexualidad que condenan moralmente. Al contrario, Copi hace del médico y de la enfermera figuras humorísticas que, lejos de condenar a Cyrille, lo animan en las locuras. 24 "Professeur : - Il faudra trouver les causes de cet excès de santé. Sans ça, nous devrions croire à un miracle. / Cyrille :J'espère que je ne serai pas forcé de me convertir! Ni encore moins de plonger dans la piscine de Lourdes. / Professeur : - Ne craignez rien, ce ne serait qu'un miracle de la science" (Copi, 1988: 28). [Mi traducción.] 
La ficción no pone en tela de juicio una realidad discriminadora, sino que aparece como un espacio de inversión de los códigos. En Una visita inoportuna lo normal parece extraño, estrategia que permite al autor proponer un sistema lógico dentro de su propio código. Frente a un tema tan serio como el sida, esta táctica aparece como una manera de burlarse de todo, incluso de la muerte, de la enfermedad y de los médicos, situando al autor por encima de los discursos excluyentes.

La muerte y el sida son los dos personajes, invisibles y no encarnados, que merodean por estas obras. Sin embargo, los autores eligen cada uno un tema privilegiado. Valdés Medellín centra su obra en la cuestión del sida, tratado como un tema social y político. Copi, por su parte, centra su argumento en la cuestión de la muerte y en las estrategias posibles para, si no evitarla, disfrutar de lo que queda.

MELODRAMA REALISTA VS FARSA TRÁGICA CAMP

La cuestión del sida se presenta en las dos obras como una cuestión social, compartida con otros personajes más o menos cercanos. Se habla mucho del sida, de la muerte, de la enfermedad y de la sexualidad. Este elemento hace eco del análisis de Antonio Marquet, quien considera que el sida es un "catalizador que polariza": "El sida viene a fracturar a la pareja, o a consolidarla. Es el elemento que ya no permite prolongar el silencio, fingir sobre la identidad sexual; es el elemento que obliga a asumir a la familia, a la sexualidad, como en $A$ tu intocable persona. Se oculta, se exhibe, se le blande como arma o se le teme: el sida es el catalizador que polariza" (Marquet, 2001: 332).
Tanto Orlando como Cyrille son invitados a hablar de la enfermedad, de la sexualidad y del placer. Podemos notar que este fenómeno se observa de manera general en la sociedad de los años ochenta, ya sea en Francia o en México. Como lo subraya Carlos Monsiváis (1997: 13): "Lógica del ocultamiento: lo que no se nombra no existe, y lo nada más filtrado, y muy despreciativamente, en las conversaciones, es sórdido de suyo. Eso obliga a una gran inocencia, fingida y real. Mientras el escándalo no ilumine el asunto, el recelo es categoría desconocida, y por tanto, la homosexualidad es impensable."

En "la muy católica nación Mexicana" (Monsiváis, 1997: 13), la cuestión sexual es totalmente tabú. Sin embargo, la "un poco menos católica nación francesa" tampoco está muy abierta para hablar de esas cuestiones. ${ }^{25} \mathrm{La}$ epidemia de sida podría ser el "escándalo" del que habla Monsiváis. Obliga a los poderes públicos a llevar campañas de prevención en los medios de comunicación, las escuelas, los hospitales, etcétera. Como no se puede hablar de prevención sin hablar de sexualidad, la cuestión sexual se convierte a partir de finales de los ochenta y principio de los noventa en una cuestión social y política central. En este aspecto, y aunque de manera distinta, tanto la obra de Copi como la de Valdés Medellín participan de esta apertura.

\section{Una ficción contra los prejuicios}

Al evitar la muerte del personaje, Valdés Medellín centra su argumento en la enfermedad, entendida en su dimensión social, es decir como blanco de 25 Cabe recordar que Felix Guattari fue condenado por "falta de respeto a la moral" en 1973 tras haber publicado "Tres billones de perversos", un número de la revista Recherches sobre la homosexualidad. 
oposición entre la comunidad gay y los discursos discriminadores. Formalmente, la obra, que se anuncia como una tragedia, se convierte en un melodrama social. La calificación de teatro "social" se impone puesto que, además de centrarse en una temática polémica en la época, Valdés Medellín articula distintos personajes que hablan, no en su nombre, sino en el de una colectividad. El periodista, que mantiene un papel supuestamente neutral, se encarga de distribuir la palabra. Aparecen así figuras que defienden la voz de la comunidad (como Antonio), el discurso excluyente de los grupos hostiles a los homosexuales (la enfermera Rodríguez y los médicos) y, finalmente, aquellos que otorgan al drama su dimensión "personal" y melodramática, como la madre y el novio.

Una voz sobresale en particular ya que corresponde con el discurso militante que el autor parece promover. Antonio ${ }^{26}$ es el personaje que asume claramente el discurso de los colectivos, o sea, un mensaje de prevención y una crítica de los discursos excluyentes.

Antonio: Hoy ya no se puede vivir la homosexualidad como se vivía cuando era joven y todavía hace unos ocho años. Y no es que esté de moralista. Soy muy burgués, es cierto, pero no es por moralina que lo digo [...] Mientras no se tenga la famosa vacuna, los homosexuales debemos, me choca la palabra debe, pero aquí no queda de otra, debemos, pues, modificar nuestro ejercer sexual, nuestra conducta, nuestro

26 Este personaje está muy probablemente inspirado en José Antonio Alcaraz, director de teatro y conocido como uno de los primeros directores de una obra gay: $Y \sin$ embargo se mueven, en 1980. Es también el dueño del bar El taller, uno de los lugares más famosos del "ambiente", tan conocido como lugar de fiesta como de militancia. José Antonio Alcaraz es una de las figuras más importantes del mundo cultural gay mexicano de la época. entorno social [...] Estamos en peligro de muerte, no podemos seguir andando, y menos cogiendo, con la inconciencia a cuestas porque terminas acostándote con la inconciencia y ya te fregaste (Medellín 1994: 51).

El discurso de Antonio es un mensaje didáctico, dirigido mayoritariamente a los homosexuales aunque no únicamente. Tiene como meta difundir el uso del condón y "el sexo consciente". La posición que el autor otorga a su personaje es significativa. Antonio habla en primera persona del plural, identificándose como homosexual: "los homosexuales debemos." Defiende una posición de "sabio" que se dirige a los jóvenes: "no se puede vivir la homosexualidad como cuando era joven.” Precisa su aversión por los vocablos que remiten a cierta obligación, como "responsabilidad" o "deber", e incluso la referencia a una forma de "moral" que rechaza. Estos elementos remiten a la constitución de la colectividad gay que soñó con una libertad absoluta y sin límites, especialmente en lo que respecta al sexo. Se puede considerar que estos elementos forman parte de cierta "mitología" autoconstruida por parte de la comunidad. El antagonismo entre los conceptos de "amor libre" y de "libertad sexual absoluta" versus los valores de "la moral burguesa" fueron centrales en el discurso de la comunidad. Semánticamente, el discurso de Antonio está escrito con un estilo coloquial, participando de cierta cercanía con el público. No es el lenguaje formal de los médicos, o el lenguaje moral de la enfermera.

Antonio identifica claramente la posición de "los otros" y aunque la condene, no se sorprende 
de la culpabilidad que el discurso excluyente hace recaer sobre los homosexuales:

Antonio: Nunca nos van a aceptar los de la sociedad de enfrente, nunca nos van a querer. Y no quiero sonar melodramático, pero es verdad. Nosotros, los culpables del sida, cómo no. Del joto caído todos hacen leña. Pues órale: que hagan leña de nosotros, pero, ¿quién nos va a quitar los orgasmos maravillosos que hemos tenido con otro hombre? [...] Nadie, nadie. Ni el sida. Porque sida y todo, las locas seguimos cogiendo y de lo lindo (Medellín, 1994: 52).

La fórmula "del joto caído todos hacen leña" es particularmente emblemática de esta idea. Antonio manifiesta una clara oposición entre la "sociedad de enfrente" y el "ambiente"; dos sociedades que no se pueden reconciliar. No obstante, en su discurso, esta fuente de oposición se sitúa en relación al cuerpo, especialmente al sexo. El "ambiente" constituye el ideal de liberación sobre prácticas sexuales diversas y liberadas de las normas sociales. Este punto se presenta como una fuente del orgullo, base de la "identidad gay". Tras el periodo de ocultamiento que sufrieron los homosexuales, la identidad gay se construyó sobre una condena de "la sociedad de enfrente", juzgada como encerrada en sus valores e incapaz de experimentar el placer. Ambas consideraciones son evidentemente construcciones discursivas que no se comprueban necesariamente en la práctica. Como lo subraya Rodrigo Laguarda en Ser gay (2009), el "ambiente" también tenía sus reglas y sus excluidos. Sin embargo, Valdés Medellín retoma aquí, casi de manera literal, discursos que configuran un modelo de identidad que, si bien no es perfecto, permite salir del ocultamiento y del sentimiento de culpa interiorizado, o sea, del sistema de violencia simbólica (Bourdieu y Passeron, 1970).

\section{El sida bajo el filtro del humor camp}

En la obra de Copi, los personajes tienen referentes históricos que se distinguen por su singularidad. No aparecen discursos colectivos o de prevención, y de hecho, la temática es menos el sida que la propia muerte. La muerte anunciada desde el principio es inevitable, pero la tragedia se ve marcada por lo que podríamos calificar de "humor camp"; es decir, como lo define MarieHélène Bourcier (2001: 186): "Una estrategia de resistencia cultural fundada sobre la conciencia compartida de que estamos encerrados en un sistema complejo de significaciones sociales y sexuales. El 'camp' propone resistir desde el interior mediante la parodia, la exageración, la teatralización, el entendimiento literal de los códigos tácitos que rigen nuestra manera de vivir y de representar (como los códigos de la masculinidad por ejemplo)." ${ }^{27}$

De hecho, Copi invierte perpetuamente lo esperado y hace de la obra un microcosmos que vuelve a definir los códigos de la "normalidad". La muerte, como la enfermedad, son fuentes privilegiadas de "exageración y teatralización" y los personajes son parodias de ellos mismos. Varias réplicas sitúan esta obra en un género indefinido, una farsa trágica, cínica y burlesca donde se puede

27 'Une stratégie de résistance culturelle, qui se fonde sur la conscience partagée du fait que l'on est pris dans un système complexe de significations sociales et sexuelles. «Le camp » propose d'y résister de l'intérieur via la parodie, l'exagération, la théâtralisation, la prise au sens littéral des codes tacites qui régissent notre manière de vivre et la représentation (les codes de la masculinité par exemple)." [Mi traducción.] 
reír de todo, especialmente de lo serio. Al principio de la obra, Hubert dice a Cyrille: "Tiene suerte de tener sida, por lo menos aquí no se corre ningún riesgo"28 (Copi, 1988: 13). Esta réplica plasma en la obra desde su mismísimo inicio el revuelto cómico relativo a la muerte. Sistemáticamente, el fallecimiento programado de Cyrille (elemento central de la tragedia) se convierte en algo risible. Así, el profesor trae un regalo a Cyrille para festejar su segundo aniversario con sida. Al mismo tiempo, el profesor felicita a su paciente por sus problemas de salud.

Profesor: ¿Algún accidente en los últimos días?

Cyrille: Dos paros cardiacos y un coma.

Profesor: Bien, muy bien [...] Demasiado bien incluso.

Cyrille: Entonces me voy a curar.

Profesor: Todo lo contrario, todo lo contrario. ¿No le estoy diciendo que ya debería estar muerto? [...] Vivirá lo que vivirá su sida. Ya cumplió dos años, volveremos a hablar en su próximo aniversario ${ }^{29}$ (Copi, 1988: 28).

El profesor, que debería regañar a Cyrille, lo felicita de lo que considera como "excesos de salud". Sin embargo, el final trágico no se cuestiona nunca, la muerte de Cyrille es inevitable. Lo importante no es la muerte por venir, sino el hecho de que a pesar de todo, Cyrille siga con vida. En la obra de Copi, el contexto real, o sea, la epidemia de sida que

28 "Vous avez de la chance d'avoir le sida, ici au moins vous ne courez aucun risque." [Mi traducción.] 29 Professeur. - Pas d'accident de santé ces derniers jours ? / Cyrille. - Deux arrêts cardiaques et un coma / Professeur. - Bien, très bien [...] trop bien même. / Cyrille. - Donc je serais guéri ? / Professeur. - Bien au contraire, bien au contraire. Puisque je vous dis que vous devriez être mort. [...] Vous vivrez aussi longtemps que votre sida. Il est déjà arrivé à l'âge de deux ans, nous en reparlerons à l'occasion de son prochain anniversaire. [Mi traducción.] alcanza un número altísimo de muertos en 1988 , está presente pero de manera liminar. Por ejemplo, Cyrille menciona la pesadez del tratamiento:

Profesor: ¿Qué toma ahora?

Cyrille: Un litro de Suramina, como todas las semanas, y mil millones de unidades de Interferón por mes, sin contar con lo cotidiano ${ }^{30}$ (Copi, 1988: 27).

En aquella época, no existía tratamiento para curar el sida (aún hoy en día y aunque hayan mejorado mucho las condiciones de las personas seropositivas, no existe un tratamiento que permita destruir el virus), pero los médicos intentaban diversos protocolos muy pesados para los enfermos. En otro momento, el profesor hace referencia a un tema controversial en el mundo médico a finales de los ochenta. Frente a lo inevitable, aconseja a Cyrille curarse con plantas: ${ }^{31}$

Profesor: Y usted, si quiere un consejo, cúrese con plantas. De cualquier modo se va a morir, y en el peor de los casos, es más agradable una taza de boldo que un goteo en vena.

Cyrille: Pero si ya tengo mi opio.

Profesor: Tome los $\operatorname{dos}^{32}$ (Copi, 1988: 57).

30 'Professeur: - Qu'est-ce que vous prenez, là? / Cyrille: - Un litre de suramine, comme toutes les semaines, et un milliard d'unités d'interféron par mois, sans compter le quotidien.” [Mi traducción.]

31 Frente a la imposibilidad de curar a las víctimas, varios médicos intentaron, si no destruir el virus, reforzar las defensas inmunitarias de los pacientes con, por ejemplo, el uso de vitaminas. Esos tratamientos tuvieron resultados interesantes: no permitían la cura de los pacientes pero sí prolongarles y mejorarles sus condiciones de vida, al contrario de los tratamientos clásicos que, al buscar la destrucción del virus, destruían el sistema inmunitario. Las industrias farmacéuticas trataron de impedir esos tratamientos considerados como "alternativos". La película Dallas buyers club de Jean-Marc Vallée (2014) aborda esta temática.

32 Professeur. - Et vous, si vous voulez un conseil, soignez- 
La obra de Copi se refiere a ciertos temas emblemáticos de la época, es decir, al contexto real de la ficción. Sin embargo, otra vez vemos que el autor busca menos un realismo didáctico que una manera de poner el juego, y mediante éste, el teatro en primer plano de la obra.

La obra hace numerosas referencias al teatro, como en esta réplica del profesor:

Profesor: ¡No pensará abandonarnos! La ciencia tiene exigencias tan imperativas como el teatro. Debería enorgullecerse de sus reiterados triunfos sobre la muerte. Es usted un héroe en este templo de la ciencia. $¿$ Cree usted que la muerte verdadera que le acecha tiene algo que envidiar a la muerte que se envuelve en negras vestiduras de un escenario? ${ }^{33}$ (Copi, 1988: 27).

Frente a un tema tan grave, especialmente en los años ochenta, Copi deja de lado la discriminación y la muerte que merodean la cuestión del sida para poner en primer plano la risa y el juego, es decir: la vida. El teatro no es un lugar de denuncia para Copi, es el espacio donde triunfa el juego, donde uno se puede reír de todo y donde los códigos sociales se pueden trastocar. Al respecto, Olivier Neveux analiza la posición subversiva de Copi: "Este es, por cierto, uno de los aportes de la obra de Copi: abrir la posibilidad de un teatro que tomaría los códigos de la ideología

vous par les plantes. Vous allez mourir de toute façon, et dans le pire des cas, une tasse de chicorée est plus agréable qu'une perfusion. / Cyrille. - [...] mais j'ai déjà mon opium. / Professeur. - Prenez les deux. [Mi traducción.]

33 Professeur. - Vous ne songez pas à nous quitter, la mort a des exigences aussi impérieuses que le théâtre. Vous devriez être fiers des succès répétés contre la mort dont vous êtes le héros dans ce temple de la science. Est-ce que la vraie mort qui vous guette a quelque chose à envier à la mort drapée en noir d'une scène de théâtre ? [Mi traducción.] dominante y los llevaría a un punto que no puede contener"

(Neveux, 2013). En este caso, la obra recurre a los códigos de la farsa y de la tragedia $\mathrm{y}$ enfoca su acción en un contexto político y social contemporáneo. Tanto la muerte como la condena social se desploman sobre los enfermos de sida. En su obra, Copi transforma la muerte en una fiesta y su personaje se califica así mismo de "loca sublime", rodeada por sus amigos y sus admiradores. Los dos anatemas son por lo tanto desviados, y la risa recuerda que el juego, el teatro y la vida son quizá las mejores armas contra la muerte y los ataques violentos que sufrieron la victimas del sida: esos marginales que la sociedad no quería ver.

\section{CONCLUSIÓN}

El cuadro espacial, los personajes y la situación ficcional de cada obra presentan semejanzas notables que nos han permitido proponer una comparación. Sin embargo, al elegir formas teatrales muy distintas —el melodrama realista didáctico y la farsa trágica camp — se proponen dos miradas diferentes sobre un tema común. Muchos elementos pueden explicar tales divergencias: el contexto sociocultural de la producción de las obras, la postura de cada autor en relación con la temática, así como la meta política y artística del autor.

Un punto común entre Gonzalo Valdés Medellín y Copi es que ambos se declararon homosexuales y que los dos participaron - $-\mathrm{y}$ Valdés Medellín lo sigue haciendo- en la "comunidad gay artística" de su país. No se 
definen explícitamente como militantes, pero se les puede considerar como actores mayores del escenario gay. Escriben, actúan y dirigen un teatro que representa a la comunidad y a sus personajes, hablan de las sexualidades, juegan con los códigos de género y cuentan historias de amor que no se preocupan del sexo. Forman parte del proceso de visibilización de una homosexualidad que ya no se concibe como "un doloroso pecado" o una "existencia de silencio".

En el teatro de Copi como en el de Medellín, las minorías ocultas salen del clóset. Los autores participaron, por lo tanto, en las dinámicas de representación que acompañaron las luchas políticas emergentes a partir de los años setenta en Francia y un poco más tarde en México. Sin embargo, esto no implica que propongan un teatro militante explícito. Gonzalo Valdés Medellín aboga por un teatro que hable "del ser humano", un teatro conmovedor detrás del cual puede aparecer un deseo de reconciliación. Copi, por su parte, destruye todos los tabúes sociales en obras que se presentan como farsas delirantes, inspirado por el universo de la "loca" y del humor "camp", es decir, según las palabras de Michel Cressole, "una noción esencialmente cultural" cuando la cuestión gay se presenta como un concepto "social y político" que busca una abolición de las categorías (incluso las de la "comunidad").

En la época del sida, los gays fueron considerados responsables de la peor epidemia del siglo XX y el escenario gay padeció tal condena. Por ejemplo, la representación de la felicidad sexual y la promoción de una sexualidad libre y plural —uno de los blancos de la reivindicación desde los setenta - se hizo más difícil. Sin embargo, esta palabra, emergente de la comunidad, que expresó un punto de vista interno y desvinculado de ciertos estereotipos, fue más necesaria que nunca. Permitió que no se escucharan únicamente las voces que condenaban a los enfermos.

Las diferencias entre ambas obras reside esencialmente en la forma dramática elegida, elección que permite poner de relieve una meta política y artística distinta. El contexto sociocultural de producción y la situación personal de cada autor puede explicar tales diferencias. Valdés Medellín escribe en 1994 pero sitúa la ficción en 1985. Adopta por lo tanto una mirada retrospectiva que le permite proponer una suerte de balance doce años después de la aparición del VIH en México. La emoción predomina en su obra, el autor recurre a ciertos procedimientos propios del melodrama como la exageración, el énfasis y el pathos. Busca conmover al espectador contando una historia de amor, destruida por el sida tanto como por los discursos que rodean la enfermedad. A pesar de este trasfondo melodramático, A tu intocable persona se presenta como una pieza teatral marcada por el realismo.

La obra de Valdés Medellín no se puede considerar como militante stricto-sensu pero es innegable que aboga por una forma de sensibilidad, de tolerancia y de apertura relativas a la sexualidad, al cuerpo y al sida. Cuando uno lee $A$ tu intocable persona veinte años después de su publicación, le da la impresión de un panorama casi exhaustivo de los discursos y de las problemáticas en juego entre 1994 y 1985. Se representan todos los discursos y los personajes claves de una historia 
de amor marcada por la enfermedad de uno de los amantes. Aparecen el enfermo, su pareja, su madre, los médicos y otras voces procedentes de la comunidad, como una figura emblemática del mundo gay militante, un reportero supuestamente neutral y una enfermera que encarna el discurso moral y católico.

Valdés Medellín articula esos discursos, entrecruza las problemáticas íntimas y las cuestiones públicas que aparecen indisociables cuando se habla de sida. Alejarse de los prejuicios que condenaron a los enfermos de sida al silencio y la vergüenza, explorar y abrir el tema de la sexualidad, de las relaciones interpersonales y ser capaz de ver el amor fuera de consideraciones homo o heterosexuales, parecen ser la meta de su obra. Condena a los discursos que consideraron el sida como una enfermedad de "marginales", aboga por una difusión de la prevención y repite varias veces "usen condón". Demuestra cómo los tenientes de la moral "católica" difundieron prejuicios casi tan nefastos como la enfermedad. Sin embargo, si Antonio podría verse como "la voz del autor" en la obra, Valdés Medellín no afirma que las dos sociedades - hetero y homo- sean irreconciliables. Al contrario, su obra aparece como un puente entre la "comunidad" y la "sociedad de enfrente", un puente construido sobre emociones como la empatía y valores como el humanismo, la tolerancia y el "dejar vivir".

La obra de Copi propone un enfoque muy distinto. Si la muerte se anuncia desde el principio, y es por lo tanto inevitable, no aparece como algo triste; el miedo a la muerte está ausente en la obra y la necesidad de vivir es omnipresente. La habitación del hospital se convierte en un lugar de reencuentros y de risas, un espacio donde se festeja la amistad y el buen vivir.

Copi recurre también a una forma de exageración y de énfasis, pero sus referencias son las de la farsa, las de la caricatura, y no las del melodrama. De hecho, Copi se aleja del realismo salvo en algunas referencias a los lugares de sociabilidad gay o a la pesadez del tratamiento contra el sida, por ejemplo. A excepción de esas elípticas referencias, el último día de Cyrille se desarrolla más bien como un sueño durante el cual todo se vive entre fantasía y realidad. El personal médico encarna de manera evidente esas diferencias con la obra de Valdés Medellín. En A tu intocable persona, los médicos y la enfermera son rígidos, tienen un discurso estereotipado y muy influido por la "buena moral". Al contrario, en la obra de Copi, son grotescos e incomparablemente más humanos. Copi trabaja una estética "loca". Según Michel Cressole, la "loca" se despega de todos los esquemas. Una loca puede ser ama de casa casada con un perro pero también travesti en los bares parisinos; "loca" es una forma de pensar más que una forma de ser. Según Cressole (1992: IV): "la loca no es elegible para la legislación", no la pueden recuperar ni los poderes políticosjudiciales, ni el discurso médico, ni las instituciones religiosas. La "loca" no se puede categorizar y por lo tanto demuestra la inutilidad de los esquemas de dominación; no sólo los reconfigura sino que imagina una posible supresión de las categorías binarias de dominación (Hombre/mujer; hetero/ homo; blanco/negro...). Está aparte -o por encima- y por eso se presenta como la única 
forma de resistir realmente a la dominación: "las instituciones reconocerán que su acción es más útil y benéfica que la militancia política" (Cressole, 1992: V). Copi elige la caricatura y lo lúdico mediante el absurdo. Si es que la risa se considera como arma, entonces es ésa la única que Copi utiliza en el combate.

Las dos obras eligen así formas dramáticas que revelan posiciones distintas. Copi está a punto de morirse cuando escribe Una visita inoportuna. En 1988, los ataques contra la comunidad son muy violentos pero el autor no parece buscar responder a tal discriminación; se sitúa al margen del combate. Retrospectivamente, su obra puede aparecer como un testimonio a favor del "buen vivir" y de la amistad. No se enfrenta con un discurso religioso (probablemente un poco menos presente en Francia que en México) o médico, sino que los desvía; los caricaturiza, los ridiculiza y, al final, los hace más humanos al ser menos realistas. Copi no aporta soluciones, no quiere entrar en el debate, en cambio se sitúa por encima de todo, tanto de la muerte como de la enfermedad.

En 1994, Valdés Medellín se ubica en otro plano: busca un teatro que plantea preguntas, un teatro humanista que busca las formas posibles de una sociedad basada en la tolerancia y la comprensión mutua. Propone un teatro basado en la empatía cuando Copi pregona un teatro basado en el cinismo. Quizás este elemento se pueda explicar por la cronología. En 1988 no existen otras soluciones que aceptar la muerte. Al parecer, Copi prefiere irse con la cara alta y una risa que se prolongue más allá del teatro. En 1994 empiezan a entreverse soluciones y la comunidad parece cada vez más dispuesta a entrar en el juego político para acceder a una forma de reconocimiento, dinámicas que se rechazaban hasta entonces. Valdés Medellín parece participar de este movimiento que promueve la consideración de la homosexualidad como una sexualidad más entre otras, sin trasfondo combativo. Para completar el panorama, se podría hacer una comparación con Angels in America de Tony Kushner, una obra americana que propone una fresca historia de los Estados Unidos en los años sida, poniendo de relieve las analogías entre las comunidades "minoritarias", raciales y sexuales y los fenómenos de opresión que sufren tales minorías en los Estados Unidos. ¿o

\section{AGRADECIMIENTOS}

Quiero agradecer a las siguientes personas que me ayudaron a corregir las pruebas del texto: Laura Bejarano Espinosa, Martín Díaz Vázquez, Anaïs Giannandrea y Gabriela Serban. También mis reconocimientos van hacía Karine Tinat y el equipo de la revista Estudios de Género que me permitieron publicar este artículo. 


\section{BIBLIOGRAFÍA}

Obras estudiadas

Copi (1988), Une visite inopportune. Paris, Christian Bourgeois.

Valdés Medellín, Gonzalo (1994), A tu intocable persona. México, Daimon.

Obras y artículos críticos

Adams, Barry D. (1998), "Structural foundations of the gay world”, en Peter M. Nardi y Beth Schneider (Coords.), Social Perspectives in Lesbian and Gay Studies: A Reader. Windsor, Routledge, pp. 220-227.

Badinter, Elisabeth (1981 [1980]), ¿Existe el amor maternal? (trad. Marta Vasallo). Barcelona, Paídos. [Título original : L'amour en plus, Histoire de l'amour maternel (XVII $\left.{ }^{e}-X X^{e}\right)$ ].

Barthes, Roland (1968), "L'effet de réel”, en Communications, vol. 11, pp. 84-89, consultado el 7 de diciembre de 2014. URL: http://www.persee.fr/web/revues/home/prescript/article/comm_05888018_1968_num_11_1_1158

Bourcier, Marie-Hélène (2001), Queer zones. Politiques des identités sexuelles, des représentations et des saviors. Paris, Balland.

Bourcier, Marie-Hélène (2011), Queer Zones 3. Paris, Amsterdam.

Bourdieu, Pierre y Jean-Claude Passeron (1970), La reproduction. Elements pour une théorie du système d'enseignement. Paris, Editions de Minuit.

Cournot, Michel (1988), “Un aperçu du dernier jour”, en Le Monde, 29 octobre 1988. [Artículo reproducido en Copi (1988), Une visite inopportune. Paris, Christian Bourgeois, pp. 93-94.]

Cressole, Michel (1992), Une folle à sa fenêtre. Paris, Gai-kitsch-camp.

Díez, Jordi, (2010), “El movimiento lésbico-gay 1978-2010”, en Ana María Tepichin, Karine Tinat y Luz Elena Gutiérrez (coords.), Los grandes problemas de México, VIII. Las relaciones de género. México, El Colegio de México, pp. 135-154. 
Foucault, Michel (1976), Histoire de la sexualité, I : La Volonté de savoir. Paris, Gallimard.

Foucault, Michel (1984 [1967]), "Dits et écrits, Des espaces autres", en Architecture, Mouvement, Continuité, núm. 5. Paris, Conférence au Cercle d'études architecturales, pp. 46-49.

Laguarda, Rodrigo (2009), Ser gay en la ciudad de México. Lucha de representaciones y apropiación de una identidad, 1968-1982. México, Ciesas.

Le Talec, Jean-Yves (2008), Folles de France. Paris, La Découverte.

Lizárraga Cruchaga, Xabier (1985), Y luego ... ¿por qué las matan? México, Los textos de la Capilla.

Lizárraga Cruchaga, Xabier (2011), entrevista realizada el 26 de noviembre del 2011 en la residencia del autor, 165 min. México.

Marquet, Antonio (2001), ¡Que se quede el infinito sin estrellas! México, UNAM.

Martel, Fréderic (2008 [1996]), Le rose et le noir. Paris, Seuil.

Mauriès, Patrick (2012 [1979]), Second manifeste camp. Paris, L'éditeur singulier.

Neveux, Olivier (2006), "Rire comme une folle... Sur d'éventuels effets politiques de la parodie La Tour de la Défense de Copi", en Recheches et Travaux, vol. 69, pp.77-89, consultado el 7 de diciembre de 2014, URL: http://recherchestravaux.revues.org/304

Niangouna, Dieudonné (2013), Acteurs de l'écriture. Paris, Solitaires intempestifs.

Piscator, Erwin (1962 [1930]), Le théâtre politique. Paris, L’Arche [primera edición en alemán].

Sontag, Susan (1984 [1964]), "Notas sobre lo camp", en Contra las interpretaciones y otros ensayos. Barcelona, Seix Barral, pp. 303-331.

Sontag, Susan (2009 [1988]), La maladie comme métaphore et Le sida et ses métaphores. Paris, Christian Bourgeois. 
Valdés Medellín, Gonzalo (2005), “Letras que transgreden y trascienden”, en Entre comillas, entrevista realizada por Francisco A. Avila, el 7 de mayo de 2005, consultada el 23 de abril de 2015, URL: http://revistaentrecomillas.blogspot.fr/2008/05/entrevista-con-gonzalo-valds-medelln.html

Fecha de recepción: 6 de noviembre de 2014

Fecha de aceptación: 4 de mayo de 2015 